\title{
PROSES KREATIF DALAM MENCIPTA BUSANA BERBAHAN LIMBAH PERCA
}

\author{
Merlina *)
}

\begin{abstract}
Idea, imagination, and creativity are the basis of visual creation. When performed in high creativity and distinguished aesthetics, visually created objects will afford fascinating outcome. Visual works can one's touch heart and mind. People can feel the surrounding visual objects. In social activities, people will always attempt to be recognized and acknowledged by the environment.

Considering that economic factor is important in human existence means recognizing the importance of object existence. It is widely acknowledged the fulfillment of primary needs will certainly be the influential factor of human's materially oriented behavior. One of such materials is the fashionable clothing. Because, fashion can represents the social status and personal identity. That is why fashion deserves further analysis, since it represents individual characters. Since such an object is expected to meet the lifestyle, it consequently will result in unique symbol in social stratum of life. This is particularly true since material quality may represent the symbol of self-existence in mass culture.
\end{abstract}

Key Words: creative, fashion, and existence

\section{ABSTRAK}

Sebuah ide, imajinasi, dan kreativitas merupakan dasar dalam menciptakan sesuatu (bentuk/visual). Visual (khususnya karya seni, apapun bentuknya) ketika disajikaan dengan kreativitas tinggi dengan gaya dan nilai estetik tersendiri akan memunculkan penilaian lain. Dari visual karya dapat menyentuh perasaan dan pemikiran seseorang, melalui benda-benda yang ada disekitar kita. Individu dalam aktifitas bermasyarakat secara sadar ataupun tidak, eksistensinya ingin diakui dan dikenal dalam lingkungannya.

Melihat pengakuan eksistensi manusia secara ekonomi, maka keberadaan benda menjadi hal yang sangat penting. Bagaimana persoalan yang mencakup pemenuhan kebutuhan primer merupakan faktor penentu tingkah laku manusia yang merucut pada materi. Salah satunya adalah busana, di mana setiap individu membutuhkannya. Karena, busana mampu menunjukan status sosial dan penanda identitas. Hal tersebut menjadi dasar mengapa pentingnya masalah ini untuk dikaji, karena benda dapat mewakili karakter pada tiap individu. Ketika benda dihadapkan pada pemenuhan gaya hidup, akan menciptakan perlambangan sendiri dalam strata sosial masyarakat. Karena, kualitas benda sudah menjadi simbol eksistensi diri dan merucut pada budaya masa.

Kata kunci: kreatif, busana dan eksistensi

\section{PENDAHULUAN}

Munculnya suatu ide dalam menciptakan karya seni dapat bermula dari sebuah kegelisahan, atau perasaan yang terdorong untuk menyatakan pengalamanpengalaman kepada orang lain. Seni dapat

* Merlina, Mahasiswa Pascasarjana Institut Seni Indonesia Yogyakarta 
tumbuh dan muncul karena dorongan perasaan dan emosi guna berbagi wawasan, ide gagasan, atau perasaan dan pengalaman kepada orang lain, layaknya seorang kreator yang melakukan berbagai cara untuk menuangkan ide gagasannya dalam menciptakan karya seninya. la melakukan berbagai aktivitas untuk menentukan media yang mampu menyalurkan perasaan dan emosinya. Di dalam proses penciptaan karya seni, kreator melakukan berbagai macam pendekatan untuk mendapatkan ide dan gagasan yang tepat. misalnya melalui coretan pada lembaran kertas, kemudian atau mencoba menyimpulkan dan menambah bila merasa masih ada yang kurang, ada juga yang langsung menuangkan ide pikiran untuk menentukan hasil karyanya.

Pentingnya pendidikan formal untuk mengenal aturan-aturan serta proses yang benar dalam merancang suatu desain, tetapi juga harus bisa "mendengar" dan "merasakan" apa yang terjadi didunia kerja dalam bidang busana secara nyata. Dampak dari mendengar dan merasakan "keluhan" atau "permintaan" konsumen tentang keinginan agar dapat tampil beda dengan orang lain, dapat memberikan kesan berbeda sesuai karakter kepribadiannya. Dari berbagai aktivitas yang dilakukan tersebut bertujuan mengumpulkan data-data informasi yang dapat mendukung pemecahannya. Aktivitas kerja dan pola pikir manusia merupakan elemen informasi yang di terima oleh panca indera, kemudian diolah hingga menimbulkan interpretasi, sehingga melahirkan sebuah karya seni yang bernilai fungsi.

Seperti halnya busana, busana yang lengkap dengan aksesorisnya merupakan kebutuhan penting yang dapat menunjang penampilan, memperindah dan mempercantik diri sehingga terlihat lebih percaya diri. Pakaian atau busana tidak hanya sekedar sebagai penutup badan saja, tapi salah satu fungsinya adalah sebagai identitas dari pemakainya. Busana sebagai penanda sosial, melalui seni berbusana, manusia menjadi lebih mudah dikenali misalnya dari kalangan mana dan apa profesinya.

Selain hal tersebut busana juga dapat memperlihatkan karakter seseorang. Karakter ini bisa dilihat dari berbagai hal, misalnya warna, motif, media (bahan) dan lain-lain. Akan tetapi hal yang paling berkarakter adalah sesuatu yang jarang atau sangat sedikit dijumpai keberadaanya, terlebih benda tersebut mempunyai sentuhan handmade. Seperti karya busana Merlin di bawah ini, gaun malam yang notabene sebuah busana diberi sentuhan handmade, dan media yang digunakan sangat jarang sekali dijumpai yaitu mengunakan perca sebagai aplikasi busananya.

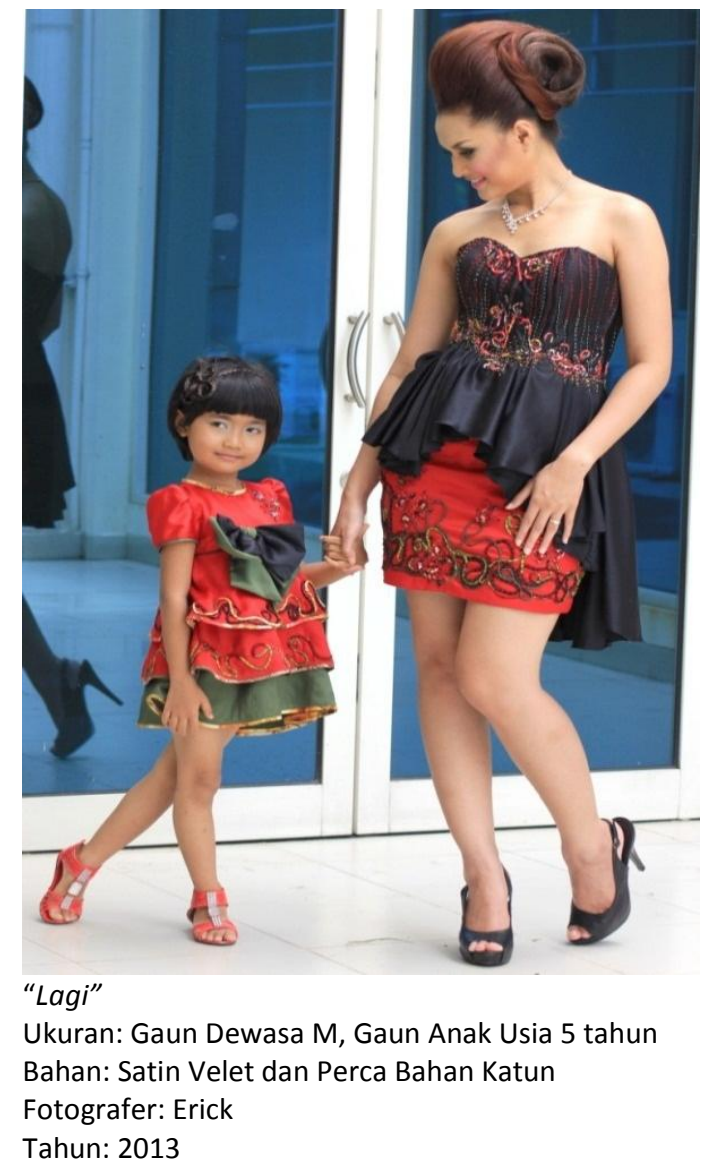


Pemanfaatkan limbah kain atau perca sebagai aplikasi pada busana pesta memberikan nilai estetik tersendiri dan penuh dengan kreativitas tinggi. Perca yang selama ini hanya dimanfaatkan sebagai bahan-bahan kerajinan yang masih memiliki nilai yang rendah. Namun aplikasi pada karya busana ini mampu memberikan nilai lebih terhadap perca. Seperti yang diungkapkan oleh Handiwirman (2007: 6), "Kemurnian dan keberadaan benda-benda yang dianggap remeh di sekitar mempunyai ekspresi dan bahasa sendiri". Melalui ekspresi, media, dan bentuk yang kemudian disatukan akan "melahirkan" bahasa tersendiri yang merucut pada makna eksistensi.

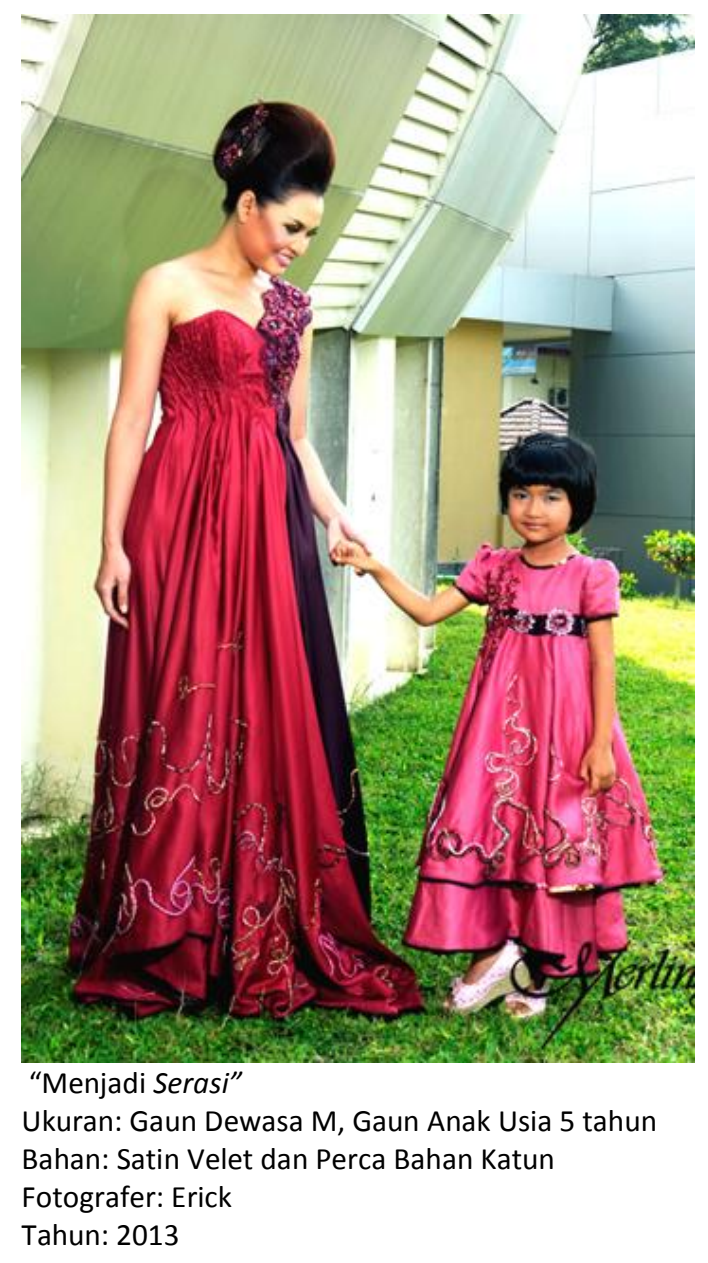

\section{PEMBAHASAN}

\section{Sifat Kreatif}

Berfikir kreatif sangat diperlukan untuk menciptakan sebuah karya seni yang kreatif atau orisinal sesuai perubahan zaman. Kreativitas merupakan suatu kemampuan yang sangat berarti dalam proses kehidupan manusia. Kreativitas melahirkan penciptaan besar yang mewarnai sejarah kehidupan umat manusia dengan karya-karya spektakulernya. Seperti Bill Gate dengan microsoft, JK. Rolling dengan novel Harry Poter, Pramudya Ananta Toer dengan bukunya, Anne Avantie, Goet Poespo, Lenny Agustin, Valentino Napitupulu, Ramli, Poppy Karim, Tex Saverio dengan karya busananya. Apa yang mereka ciptakan adalah karya orisinal yang luar biasa dan bermakna, sehingga orang terkesan dan memburu karyanya.

Jika ditinjau dari penciptaan sebuah karya seni, kreativitas merupakan prioritas penting yang memungkinkan penemuan-penemuan ide baru. Berpikir kreatif adalah berpikir secara konsisten dan terus menerus untuk menghasilkan sesuatu yang inovatif atau orisinil sesuai dengan kebutuhan. Penelitian Brookfield (1987: 63) menunjukkan bahwa orang yang kreatif biasanya: 1) Sering menolak teknik yang standar dalam menyelesaikan masalah; 2) Mempunyai ketertarikan yang luas dalam masalah yang berkaitan maupun tidak berkaitan dengan dirinya; 3) Mampu memandang suatu masalah dari berbagai perspektif ; 4) Cenderung menatap dunia secara relatif dan kontekstual, bukannya secara universal atau absolut; 5) Biasanya melakukan pendekatan trial and error dalam menyelesaikan permasalahan yang memberikan alternatif, berorientasi ke depan dan bersikap optimis dalam menghadapi perubahan demi suatu kemajuan. 
Dikatakanya bahwa kreativitas dapat dilihat dari 3 aspek yakni sebuah kemampuan, perilaku, dan proses.

Kreativitas adalah sebuah kemampuan untuk memikirkan dan menemukan sesuatu yang baru, menciptakan gagasan-gagasan baru dengan cara mengkombinasikan, mengubah atau menerapkan kembali ideide yang telah ada.

Kreativitas adalah sebuah perilaku menerima perubahan dan kebaruan, kemampuan bermain-main dengan berbagai gagasan dan berbagai kemungkinan, cara pandang yang fleksibel, dan kebiasaan menikmati sesuatu.

Kreativitas adalah proses kerja keras dan berkesimbungan dalam menghasilkan gagasan dan pemecahan masalah yang lebih baik, serta selalu berusaha untuk menjadikan segala sesuatu lebih baik.

\section{Unsur Desain}

Tidak hanya kreatif, terciptanya sebuah karya seni tidak lepas dari sebuah ide, dan gambaran visual yang di dalamnya membutuhkan komposisi atau satu kesatuan dari unsur-unsur rupa. Karena, seni rupa merupakan salah satu kesenian yang mengacu pada bentuk visual atau sering disebut bentuk perupaan. Penyusunan unsur rupa dalam mewujudkan bentuk pada seni rupa diperlukan hukum atau asas penyusunan guna menghindari komposisi rupa yang kacau. Dalam hal ini prinsip atau unsur desain sangat dibutuhkan, dalam (Darsono Sony Kartika, 2007:70) unsur rupa dibagi 5 yaitu:

\section{Unsur Garis}

Pada dunia seni rupa sering kali kehadiran "garis" bukan saja sebagai garis melainkan kadang sebagai simbol emosi yang diungkapkan lewat garis atau goresan. Goresan atau garis yang dibuat oleh seorang seniman akan memberikan kesan psikologis yang berbeda pada setiap garis yang dihadirkan. Sehingga hal tersebut mampu menumbuhkan karakter tersendiri pada setiap seniman.

Garis merupakan medium yang paling sederhana sebagai pencapaian yang paling sederhana dibanding dengan yang lain. Garis juga merupakan medium yang penting sebagai pengantar informasi dalam sebuah karya yang dihadirkan. Seperti perannya dalam menggambarkan sesuatu secara representatif, seperti yang terdapat pada gambar ilustrasi di mana garis merupakan medium untuk menerangkan kepada orang lain. Garis juga merupakan simbol ekspresi dari ungkapan seniman, seperti garis-garis yang terdapat dalam seni non figuratif atau juga pada seni ekspresionisme dan abstraksionisme.

Dari hal tersebut, semuanya tergantung bagaimana merasakan itensitas garis yang tergores pada setiap karya seni. Setiap garis yang tergores mempunyai kekuatan tersendiri dan butuh pemahaman, dan pengalamaan hal tersebut akan kita dapatkan.

\section{Unsur Shape (Bangun)}

Suatu bidang kecil yang terjadi karena dibatasi oleh sebuah kontur atau warna yang berbeda atau oleh gelap terang pada arsiran atau tekstur disebut shape. Di dalam karya seni, shape digunakan sebagai simbol perasaan seniman di dalam menggambarkan obyek ciptaannya, maka tidaklah mengherankan apabila seseorang kurang dapat menangkap atau mengetahui secara pasti tentang obyek hasil pengolahannya. Karena kadang-kadang shape tersebut mengalami beberapa perubahaan di dalam penampilannya yang sesuai dengan gaya dan cara mengungkapkan secara pribadi seorang seniman. Bahkan perwujudan yang terjadi akan semakin jauh berbeda dengan obyek sebenarnya. Hal tersebut menunjukkkan 
adanya proses yang terjadi di dalam dunia bukan sekedar terjemahan dari pengalaman tertentu atau sekedar apa yang dilihatnya.

Shape (bidang) yang terjadi: (a) shape yang menyerupai wujud alam (figur); dan (b) shape yang tidak sama sekali menyerupai wujud alam (non figur). Keduanya akan terjadi menurut kemampuan senimannya dalam mengolah obyek. Di dalam pengolahan objek akan terjadi perubahaan wujud sesuai dengan selera maupun latar belakang sang seniman. Perubahan wujud tersebut antara lain: stilisasi, distorsi, transformasi, dan disformasi.

Stilisasi merupakan cara penggambaran untuk mencapai bentuk keindahan dengan cara menggayakan objek atau beenda yang digambar, yaitu dengan cara menggayakan setiap kontur pada objek atau benda tersebut. Seperti: karya seni yang banyak menggunakan bentuk stilisasi yaitu penggambaran ornamen untuk; motif batik, tatah sungging kulit, lukisan dekoratif, dan lain sebagainyaa.

Distorsi adalah penggambaran bentuk yang menekankan pada pencapaian karakter, dengan cara merubah ukuran wujud atau objek-objek tertentu pada benda yang digambar, misalnya pada penggambaran Gatotkaca pada wayang kulit purwa, semua shape dibuat menjadi sangat kecil. Demikian juga pada penggambaran topeng: warna merah, mata melotot, untuk melebihkan bentuk karakter figur angkara murka pada topeng Raksasa pada Wayang Wong di Bali atau topeng Klana dari cerita Panji di Jawa.

Transformasi adalah penggambaran bentuk yang menekankan pada pencapaian karakter, dengan cara memindahkan wujud atau figur dari obyek lain ke obyek yang digambar. Penggambaran manusia berkepala binatang pada pewayangan untuk menggambarkan perpaduan sifat antara binatang dan manusia, menggambarkan manusia setengah dewa, semuanya mengarah pada penggambaran wujud untuk mencapai karakter ganda.

Disformasi merupakan penggambaran bentuk yang menekankan pada interpretasi karakter, dengan cara mengubah beentuk obyek dengan cara menggambar obyek tersebut dengan hanya sebagian yang dianggap mewakili, atau pengambilan unsur tertentu yang mewakili karakter hasil interpretasi yang sifatnya sangat hakiki. Perubahaan bentuk semacam ini banyak dijumpai pada seni lukis modern; unsur-unsur yang dihadirkan merupakan komposisi yang setiap unsurnya menimbulkan getaran karakter dari wujud ekspresi simbolis.

\section{Unsur Texture (Rasa Permukaan Bahan)}

Terkstur merupakan unsur rupa yang menunjukkan rasa permukaan bahan, yang sengaja dibuat dan dihadirkan dalam susunan untuk mencapai bentuk rupa, sebagai usaha unttuk memberikan rasa tertentu pada permukaan bidang pada perwajahan bentuk pada karya seni rupa secara nyata atau semu. Tekstur buatan merupakan tekstur yang sengaja dibuat atau hasil penemuan: kertas, logam, kaca, plastik dan lain sebagainya. Sedang istilah tekstur alami merupakan wujud rasa permukaan bahan yang sudah ada secara alami, tanpa campur tangan manusia. Tekstur dapat dibuat dengan teknik kolase, dengan menempelkan berbagai bahan, menempelkan potongan-potongan kertas, kayu, kain atau dengan menggunakan bubur kertas, bubur kayu, beberapa barang bekas dan lain sebagainya.

\section{Unsur Warna}

Suatu benda dapat dikenali dengan berbagai warna seperti merah, kuning, hijau, dan lain sebagainya, karena secara alami mata kita dapat menangkap cahaya 
yang dipantulkan dari permukaan benda tersebut. Benda yang berwarna merah, sebenarnya karena ia memantulkan warna merah yang ditangkap oleh mata melalui retina menembus kesadaran kita, untuk selanjutnya benda yang tampak tersebut sebagai benda yang berwarna merah. Demikian pula terhadap benda yang berwarna lain, pada dasarnya sama. Namun apabila kita amati secara lebih teliti, warna pada benda-benda tersebut tidak mutlak, melainkan setiap warna akan dipengaruhi oleh lingkungannya, misalnya warna "merah" akan mempunyai intensitas berbeda apabila dikelilingi warna kuning dan akan berbeda apabila dikelilingi dengan warna hijau dan sebaliknya. Warna putih akan semakin putih apabila didekatkan dengan warna gelap.

Warna sebagai salah satu elemen atau medium seni rupa, merupakan susunan yang sangat penting, baik dibidang seni murni maupun seni terapan. Bahkan lebih jauh dari pada itu warna sangat berperan dalam segala aspek kehidupan. Hal ini dapat dilihat dari berbagai benda atau peralatan yang digunakan manusia yang selalu diperindah dengan penggunaan warna; mulai dari pakaian, perhiasan, peralatan rumah tangga, dari kebutuhan sehari-hari sampai barang eksklusif semua memperhitungkan kehadiran warna. Demikian eratnya hubungan warna dengan kehidupan manusia, maka warna mempunyai peranan penting, yaitu: warna sebagai warna, sarana sebagai representasi alam, warna sebagai simbol atau lambang, dan warna sebagai ekspresi.

Warna sebagai warna, kehadiran warna tersebut sekedar untuk memberi tanda pada suatu benda atau barang, atau hanya untuk membedakan ciri benda satu dengan yang lain tanpa maksud tertentu dan tidak memberikan pretensi apapun.

Warna sebagai representasi alam. Kehadiran warna merupakan penggambaran obyek secara nyata, atau penggambaran dari suatu obyek alam sesuai dengan apa yang dilihatnya. Misalnya warna hijau untuk menggambar daun, rumput, dan biru untuk laut, gunung, langit dan lain sebagainya. Warna-warna tersebut sekedar memberikan ilustrasi dan tidak mengandung maksud lain kecuali memberikan gambaran dari apa yang dilihatnya. Warna-warna ini banyak dipakai oleh kaum naturalis dan realitas dan juga pada kerya representasi lain.

Warna sebagai tanda atau simbol. Di sini kehadiran warna melambangkan sesuatu yang merupakan traddisi atau pola umum. Kehadiran warna di sini banyak digarap oleh seniman tradisi dan banyak dipakai untuk memberikan warna pada wayang, batik tradisional, dan tata rupa lain yang punya citra tradisi. Kehadiran warna di sini untuk memberikan tanda tertentu yang sudah merupakan satu kebiasaan umum atau pola umum, misal tanda merah, hijau, dan kuning lampu jalan.

Demikian juga lambang tertentu yang dipakai di dalam karya seni yang menggunakan pola tertentu seperti pada: logo, batik, wayang, dan pada busana tradisi misalnya warna merah dapat berarti penggambaran rasa marah, gairah cinta yang membara, bahaya, berani dan lainlain. Warna putih dapat berarti suci, tak berdosa, setia dan lain sebagainya. Warna kuning berarti kecewa, pengecut, sakit hati, duka, misteri dan sebagainya. Biru melambangkan kecerahan, keagungan dan sebagainya. Hijau melambangkan kesuburan, kedamaian, kerukunan, dan kesejukan. Hitam adalah lambang kematian, frustasi, kegelapan, tak puas diri dan sebagainya.

Ruang dan Waktu, ruang dalam unsur rupa merupakan wujud tiga dimenssi yang mempunyai panjang, lebar, dan tinggi. Untuk meningkat dari satu matra ke matra yang lebih tinggi dibutuhkan waktu. Sehingga untuk memahami dan 
menghayati unsur-unsur rupa di dalam karya seni tetap dibutuhkan waktu. Memang ada perbedaan yang terjadi tentang waktu yang terjadi pada seni pertunjukkan dan seni rupa. Seni pertunjukkan terikat dalam ruang dan waktu yang disajikan, sedangkan waktu dalam seeni rupa merupakan waktu successive. Waktu yang digunakan di dalam penghayatan tidak dapat hanya berlangsung secara simultan tetapi secara bertahap untuk mencapai kedalaman estetika, misalnya kalau kita menghayati seni lukis, walaupun tidak terikat oleh waktu, namun tetap dibutuhkan waktu secara bertahap, sekarang, nanti, besok, lusa untuk dapat memahami simbol estetika yang ada pada seni lukis yang disajikaan. Apabila kita melihat bangunan bertingkat, kita juga tidak dapat melihat secara simultan, kita akan melihat secara bertahap dan membutuhkan waktu, namun semuanya merupakan waktu yang tidak terikat oleh waktu yang disajikan.

Ruang dalam seni rupa dibagi atas dua macam yaitu ruang nyata dan ruang semu. Ruang semu, artinya indera penglihatan menangkap bentuk dan ruang sebagai gambaran sesungguhnya yang tampak pada kanvas atau karya dua dimensi seperti yang bisa kita lihat pada karya lukis, fotografi, desain, karya ilustrasi dan sebagainya. Ruang nyata adalah bentuk dan ruang yang benar-benar dapat dibuktikan dengan indera peraba.

\section{Seni Penunjang Eksistensi}

Setiap karya seni yang berkualitas tentunya memiliki unsur-unsur seperti di atas akan tetapi tiap karya tentunya memiliki ciri khas, yang berbeda satu sama lain. Mengungkapkan karakteristik karya seni rupa dua dimensi tentu berbeda dengan karya seni rupa tiga dimensi. Karakteristik karya seni dua dimensi terlihat dari:

1. Segi bentuk atau wujudnya.
2. Teknik yang digunakan.

3. Fungsi serta maknanya.

Ketiga bagian tersebut saling berhubungan, bentuk karya terwujud karena teknik dan proses pembuatan. Bentuk juga berkaitan dengan hubungan atau fungsi. Demikian bentuk berkait dengan makna. Coba perhatikan dua karya seni rupa sebuah gambar ilustrasi atau dua dimensi dan sebuah karya patung atau tiga dimensi. Perhatikan dari segi bentuk-nya, proses pembuatanya, terutama teknik pengerjaannya. Apakah ada perbedaan? Membuat gambar ilustrasi dengan menggunakan pensil di atas kertas. Sedangkan membuat patung (kayu, batu, atau bahan lainnya) tidak menggunakan pensil tapi peralatan cukilan atau pahatan. Perkirakan juga kesulitan dalam pembuatannya, waktu yang digunakan untuk membuat dan hal-hal lain yang berhubungan dengan teknik pembuatan, Nyatakan tanggapan tersebut sesuai dengan penilaian subyektif dan objektif.

Menganalisis dan menanggapi karya seni rupa tiga dimensi bisa jadi lebih menarik, karena pada karya tiga dimensi bendanya lebih nyata. Dari segi gagasan tentu akan beragam, dari segi bahan juga bermacam-macam, bahkan segi teknikya terlihat berbeda. Biasanya dalam pengerjaan karya tiga dimensi lebih lama dibandingkan dengan karya dua dimensi.

Karya seni rupa dua dimensi dan tiga dimensi bermacam-macam, maka tentu saja gagasan, bahan atau bentuk dan tekniknya bermacam-macam pula. Masingmasing karya akan memiliki arti yang berbeda, dengan mengetahui keberagaman bentuk, teknik dan fungsinya maka nilai karya akan semakin bertambah. Nilai dalam kehidupan manusia sejak dahulu sampai sekarang nilai mempunyai peranan yang amat penting, bahkan boleh dikatakan pada dasarnya seluruh kehidupan manusia berkisar pada usahausaha mencipatakan, memperjuangkan 
dan mempertahankan macam-macam nilai (The Liang Gie, 2004:107).

Proses visualisasi karya tidak jauh berbeda dengan bahasa kosa-kata, yaitu menyusun dan membongkar kembali elemen-elemen tersebut guna menentukan ide gagasan, perbedaan yang paling menonjol adalah bentuk bangunannya, yaitu dalam susunan kosa-kata adalah kata-kata yang bermakna lain. Sedangkan dalam bahasa visual akan memperoleh bentuk dan bangunan yang baru di samping makna yang universal. Hal ini tergantung dari masing-masing pengamat sesuai dengan latar belakang seninya masing-masing, namun demikian penting sebuah visi dan misi dalam setiap karya yang bertujuan mencapai suatu interpretasi. Setiap karya seni diciptakan dengan tujuan untuk memenuhi fungsi dan aktivitas hidup untuk meningkatkan harkat dan martabat seseorang. Tidak ada satupun karya seni yang tercipta luput dari kegunaan (SP. Gustami, 1999:31). Seperti halnya sebuah karya seni, diciptakannya karya seni bertujuan guna memenuhi fungsi dan segala kebutuhan khususnya gaya hidup seseorang atau lebih meningkatkan harkat dan martabat seseorang.

Melihat pengakuan eksistensi manusia secara keseluruhan, maka keberadaan benda atau suatu karya seni menjadi hal yang penting. Berbagai persoalan yang mencakup bagaimana mencari makan, tempat berlindung, tempat berteduh (rumah), pakaian, dan lain sebagainya merupakan faktor penentu tingkah laku manusia yang merucut kepada materi. Pikiran, gerak-gerik manusia, cinta, rasa keadilan, dan seluruh ungkapan manusia semuanya dipecahkan dalam proses-proses benda atau materi (Jean Baudrillard, 2004:11).

Jika hal-hal materi merupakan faktor penentu dari tingkah laku (kesadaran) manusia, maka ia adalah wujud dalil dari teori "materialisme ekonomis" (Jean Baudrillard, 2004). Dan merucut pada sifat konsumtif, di mana benda-benda yang dibutuhkan tidak digunakan sebagaimana fungsinya, melainkan digunakan sebagai tanda pengakuan eksistensi diri. Dengan demikian, eksistensi manusia itu sematamata ada dalam kesadaran yang ditentukan oleh modus kebendaan (Muzairi, 2002:11). Hal tersebut menunjukkan nilai fungsi benda yang dikonsumsi memiliki nilai eksistensi kuat, ketika benda tersebut dihadirkan dalam masyarakat, keberadaan benda-benda itu memiliki citra atau kebanggaan tersendiri.

Peranan benda dewasa ini tidak lagi berfungsi sebagaimana fungsi aslinya, karena keunikan, kekhususan, hand made, kualitas, corak, dan warna baru (sesuai trend) dan lain melambangkan pandangan masyarakat terhadap nilai. Benda mempunyai kekuatan simbolik dan dijadikan sebagai pengukur eksistensi. Ditemukannya nilai benda sebagai pengukur ekistensi berdasar pada pengamatan pemakaian atau konsumsi benda atau barang yang memiliki kecenderungan berbeda walaupun memiliki fungsi sama. Di indonesia sendiri, kecenderungan umum dalam menentukan simbol sosial dan identitas kultural di ukur melalui gaya pakaian, mobil, atau produk lainnya sebagai komunikasi simbolik (Yasraf Amir Piliang, 2004:188).

\section{PENUTUP}

Pada hakekatnya manusia adalah mahkluk bebas yang mempunyai imajinasi tinggi dan peka terhadap lingkungannya, yang mampu untuk bertindak di luar batas kontrol struktur pranata sosialnya di mana individu itu berasal. Manusia secara aktif dan kreatif mampu mengembangkan dirinya melalui respon-respons terhadap rangsangan-rangsangan apa yang dipelajari dalam lingkungan sekitarnya. Karena dalam 
perilaku setiap manusia selalu dikaitkan dengan tindakannya dalam memilih dan mengambil keputusan dari kemungkinankemungkinan yang dihadapinya beserta dengan tanggung jawabnya.

Secara hakiki manusia merupakan makhluk sosial. Hal ini tercermin dalam sejarah kehidupan manusia yang sejak lahir membutuhkan pergaulan guna memenuhi kebutuhan hidup, baik kebutuhan yang bersifat batiniah maupun yang lahiriah. Untuk memenuhi kebutuhan tersebut manusia diharuskan mampu menyesuaikan diri dengan alam lingkungan. Proses penyesuaian diri dapat diartikan dengan cara mengubah diri sesuai dengaan keadaan lingkungan, baik secara aktif maupun pasif.

Dalam proses sosial, individu manusia dipandang sebagai pencipta realitas sosial yang beragam. Seperti dalam penggunaan waktu, uang, ruang, dan berbagai objek yang saling berkaitan. Seperti halnya cara berpakaian, cara berkomunikasi, cara makan, kebiasaan di rumah, di kantor dan lain sebagainya sesuai dengan pilihannya. Di sisi lain hal ini menjadi pilihan ketika dihadapkan dengan lingkungannya, dan sudah menjadi kebutuhan akan keberadaan dirinya, karena eksistensi manusia itu pada hakekatnya membutuhkan pengakuan dari orang lain. Tidak seorang pun yang mampu menjadi makhluk hidup sendirian dan bereksistensi secara individual (Muzairi, 2002:57). Demi bereksistensi, manusia menciptakan atau mencari karya-karya seni yang kreatif lain dari yang lain.

\section{DAFTAR PUSTAKA}

Amir Piliang, Yasraf. (2004), Dunia Yang Dilipat: Tamasya Melampui Batasbatas Kebudayaan, Jalasutra, Yogyakarta.
Brookfield. (1987), Developing Critical Thinkers. San Fransisco: Jossey Bass Publiser.

Baudrillard, Jean. (2004), Consumption Society atau Masyarakat Konsumsi, Terjemahan Wahyunto. (2004), Kreasi Wacana, Yogyakarta.

Gie, The Liang. (2004), Filsafat Keindahan. Pusat Belajar Ilmu Berguna (PUBIB), Yogyakarta.

Gustami, SP. (1999), SENI KERAJINAN MEBEL UKIR JEPARA, Kajian Estetik melalui Pendekatan Multidisiplin, Kanisius, Yogyakarta.

Handiwirman. (24-7 September 2007), Objects for a Commission Project, Archaeology of a Hotel Room, Nadi Gallery

Kartika, Darsono Sony. (2007), Estetika, Rekayasa Sains, Bandung.

Muzairi, (2002), Eksistensialisme Jean Paul Sartre: Sumur Tanpa Dasar Kebebasan Manusia, Pustaka Pelajar, Yogyakarta.

Salim, Peter, \& Yenny Salim. (1995), Kamus Bahasa Indonesia Komtemporer, Modern Press, Jakarta. 